\title{
Do fantástico em literatura ${ }^{1,2}$
}

\author{
Charles Nodier
}

RÉSUMÉ: Écrivain français du XIXé siècle, Charles Nodier est né à Besançon le 29 avril 1780 et mort le 27 janvier 1844 à Paris. Dans cet article, Nodier a établi le lien entre le romantisme et le fantastique, en montrant - avant les autres théoriciens - le rapport entre le fantastique et le sentiment de décadence. Il qualifiait le romantisme de "seule littérature essentielle de l'âge de décadence ou de transition où nous sommes parvenus"; en d'autres termes, "la littérature fantastique surgit, comme le songe d'un moribond, au milieu des ruines du paganisme, dans les écrits des derniers classiques grecs et latins..."

MOTS-CLÉS: littérature, fantastique, imagination.

Se procurarmos como teve de proceder a imaginação do homem na escolha de suas primeiras fruições, chegaremos naturalmente a acreditar que a primeira literatura, estética mais por necessidade do que por escolha, limitou-se, por muito tempo, à expressão ingênua da sensação. Ela comparou, um pouco mais tarde, as sensações entre si, deleitou-se em desenvolver as descrições, em perceber os aspectos característicos das coisas, em substituir as palavras pelas figuras. Tal é o objeto da poesia primitiva. Quando esse gênero de impressões foi modificado e quase gasto por um longo hábito, o pensamento elevou-se do conhecido ao desconhecido. Ela comparou as leis ocultas da sociedade, estudou as forças secretas da organização universal; escutou, no silêncio das noites, a harmonia maravilhosa das esferas, inventou as ciências contemplativas e as religiões. Esse ministério imponente foi a iniciação do poeta à grande obra da legislação. Ele se en-

\footnotetext{
${ }^{1}$ NODIER, Charles. DU FANTASTIQUE EN LITTÉRATURE. Paris: Chimères, 1989 [Barbe bleue, collection dirigée par David Gravier, Anne Wickers], pp.9-38.

${ }^{2}$ Tradução de Maria Regina Borges Osório, Maria Lucia Meregalli. Revisão de Patrícia Chittoni Ramos Reuillard
} 
controu devido a essa autoridade que nele se tinha revelado, magistrado e pontífice, e instituiu-se acima de todas as sociedades humanas um santuário sagrado do qual ele não mais se comunicou com a terra senão por instruções solenes, do fundo da sarça ardente, do alto do Sinai, das alturas do Olimpo e do Parnaso, das profundezas do antro da Sibila, através das sombras dos carvalhos proféticos de Dodone ou dos bosquedos da Egéria. A literatura puramente humana achou-se reduzida às coisas ordinárias da vida positiva, mas não havia perdido o elemento inspirador que a divinizou na primeira idade. Só que, como suas criações essenciais estavam feitas e o gênero humano as havia recebido em nome da verdade, ela se perdeu voluntariamente em uma região ideal menos imponente, mas não menos rica em seduções e, em suma, inventou a mentira. Foi uma carreira brilhante e incomensurável, em que, abandonada a todas as ilusões de uma credulidade dócil, por ser voluntária, aos prestígios ardentes do entusiasmo, tão natural aos povos jovens, às alucinações apaixonadas dos sentimentos que a experiência ainda não desenganou, às vagas percepções dos terrores noturnos, da febre e dos sonhos, aos devaneios místicos de um espiritualismo terno até à abnegação ou levado ao fanatismo, aumentou rapidamente seu domínio de descobertas imensas e maravilhosas, ainda mais surpreendentes e multiplicadas que as que lhe fornecera o mundo plástico. Logo todas essas fantasias tomaram corpo, todos esses corpos factícios uma individualidade absoluta e especial; todas essas individualidades, uma harmonia, e o mundo intermediário foi encontrado. Dessas três operações sucessivas, a da inteligência inexplicável que fundara o mundo material, a do gênio divinamente inspirado que adivinhara o mundo espiritual, a da imaginação que criara o mundo fantástico, compôs-se o vasto império do pensamento humano. As línguas conservaram fielmente os traços dessa geração progressiva. $\mathrm{O}$ ponto culminante de seu curso perde-se no seio de Deus, que é a sublime ciência. Denominamos, ainda, superstições, ou ciência das coisas elevadas, essas conquistas secundárias do espírito sobre as quais a própria ciência de Deus apóia-se em todas as religiões e cujo nome indica, em seus elementos, que elas estão ainda colocadas além de todas as metas triviais. $\mathrm{O}$ homem puramente racional está no último grau. É no segundo, isto é, na região intermediária do fantástico e do ideal, que seria preciso colocar o poeta, em uma boa classificação filosófica do gênero humano.

Eu disse que a própria ciência de Deus se apoiara no mundo fantástico ou superstante, e esta é uma das coisas que é quase inútil demonstrar. Considero aqui somente os empréstimos que ela fez da invenção fantástica em todas as nações, e os limites estreitos que me prescrevi não me permitem multiplicar os exemplos que, aliás, se apresentam facilmente a todos os 
espíritos. Quem não se lembra, à primeira vista, dos amores tão misteriosos dos anjos, apenas nomeados na Escritura, com as filhas dos homens, da evocação da sombra de Samuel pela velha pitonisa de Endor, essa outra visão sem forma e sem nome, que mal se manifestava como um vapor confuso, e cuja voz assemelhava-se a um pequeno sopro, esta mão gigantesca e ameaçadora que escreveu uma profecia de morte, em meio a festins, nos muros do palácio de Balthazar e, sobretudo desta incomparável epopéia do Apocalipse, concepção grave, terrível, opressiva para a alma quanto seu motivo, como o último julgamento das raças humanas, lançado aos olhos das jovens Igrejas por um gênio de previsão que parece ter antecipado todo o futuro, e inspirar-se na experiência da eternidade!

O fantástico religioso, se é permitido exprimir-se assim, foi necessariamente solene e sombrio, porque só devia tratar da vida positiva através de impressões sérias. A fantasia puramente poética revestiu-se, ao contrário, de todas as graças da imaginação. Teve por objeto somente apresentar sob uma aparência hiperbólica todas as seduções do mundo positivo. Mãe de gênios e de fadas, ela própria soube tomar às fadas os atributos de seu poder e os milagres de sua varinha. Sob seu prisma prestigioso, a terra só pareceu abrir-se para descobrir rubis com fogos ondulantes, safiras mais puras que o azul do céu; o mar apenas fez rolar coral, âmbar e pérolas sobre suas margens; todas as flores transformaram-se em rosas no jardim de Sadi, todas as donzelas em huris no paraíso de Maomé. Foi assim que nasceram, no país mais favorecido da natureza, esses contos orientais, galeria resplandecente dos prodígios mais raros da criação e dos sonhos mais deliciosos do pensamento, tesouro inesgotável de jóias e de perfumes. Aquele que busca inutilmente uma compensação passageira para o amargo tédio de sua realidade provavelmente ainda não leu As Mil e Uma Noites. Da Índia, esta Musa caprichosa, de agradável adereço, véus esvoaçantes, cantos mágicos, aparições maravilhosas, suspendeu seu primeiro vôo sobre a Grécia nascente. A primeira idade da poesia terminava com suas invenções místicas. O céu mitológico era povoado por Orfeu, por Linus, por Hesíodo. A Ilíada completara essa corrente maravilhosa do mundo sublime, juntando a seu derradeiro elo os heróis e os semideuses, em uma história sem modelo até então, onde o Olimpo comunicava-se pela primeira vez com a terra, por sentimentos, paixões, alianças e combates. A Odisséia, segunda parte dessa grande bilogia poética, não preciso de outras provas que foi concebida pelo gênio sem rival que concebera a primeira, mostrou-nos o homem em relação com o mundo imaginário e o mundo positivo, nas viagens aventurosas e fantásticas de Ulisses. Tudo se sente, aí, do sistema de invenção dos orientais; tudo manifesta a exuberância desse princípio criador que acabava de conceber 
as teogonias, e que difundia abundantemente o supérfluo de sua poligenesia fecunda no vasto campo da poesia, parecido com o hábil escultor que, de restos da argila da qual formou a estátua de um Júpiter ou de um Apolo, distrai-se a modelar, sob seus dedos, as formas bizarras, mas ingênuas e características, de um grotesco, e que improvisa, sob os traços disformes de Polifemo, a caricatura clássica de Hércules. Que prosopopéia mais natural e mais atrevida, ao mesmo tempo, do que a história de Caríbdis e de Cila? Não era assim que os antigos navegadores deviam representar-se esses dois monstros do mar, e o espantoso tributo que estes impõem à nau inexperiente que ousa experimentar seus perigos e o rugido das ondas que gritam saltando em seus rochedos? Se você não ouviu falar ainda das melodias insidiosas da sereia, dos encantamentos mais sedutores de uma feiticeira enamorada que o cativa por guirlandas de flores, da metamorfose do curioso temerário que se encontra subitamente tomado, em uma ilha desconhecida aos viajantes, pelas formas e instintos de um animal selvagem, peça notícias disso ao povo ou a Homero. A descida do rei de Ítaca aos infernos lembra, em proporções gigantescas e admiravelmente idealizadas, as goules ${ }^{3}$ e os vampiros das fábulas levantinas, que a sábia crítica dos modernos recrimina em nossa nova escola; tanto os piedosos adeptos da Antigüidade homérica, aos quais é tão ridiculamente confiada a guarda das boas doutrinas em nosso país, estão longe de compreender Homero, ou mal se lembram de o haver lido!

O fantástico exige à verdade uma virgindade de imaginação e de crenças que falta às literaturas secundárias, e que só se reproduz nelas depois dessas revoluções cuja passagem renova tudo; mas, então, e quando as próprias religiões, abaladas até em seus fundamentos, não falam mais à imaginação ou só lhe trazem noções confusas, gradualmente obscurecidas por um ceticismo inquieto, é preciso que essa faculdade de produzir o maravilhoso da qual a natureza a dotou se exerça sobre um gênero de criação mais vulgar e mais bem apropriado às necessidades de uma inteligência materializada. $\mathrm{O}$ aparecimento das fábulas recomeça no momento em que termina o império dessas verdades reais ou convencionais que emprestam um resquício de alma ao usado mecanismo da civilização.

Eis o que tornou o fantástico tão popular na Europa nos últimos anos, e o que faz dele a única literatura essencial da idade de decadência ou de transição, a qual alcançamos. Devemos, mesmo, reconhecer nisso um benefício espontâneo de nossa organização; pois se o espírito humano não se

${ }^{3}$ Fêmeas dos vampiros das lendas orientais; seres do além-túmulo como os mortos-vivos e zumbis. (N. de T.) 
comprazia ainda em vivas e brilhantes quimeras, quando enfrentou todas as repugnantes realidades do mundo verdadeiro, essa época de desengano seria vítima do mais violento desespero, e a sociedade ofereceria a revelação assustadora de uma necessidade unânime de dissolução e de suicídio. Não se deve, pois, clamar tanto contra o romântico e contra o fantástico. Essas pretensas inovações são a expressão inevitável dos períodos extremos da vida política das nações e sem elas mal sei o que nos restaria hoje do instinto moral e intelectual da humanidade.

Assim, com a queda da primeira ordem social das coisas, cuja memória conservamos, a da escravidão e a da mitologia, a literatura fantástica surgiu, como o sonho de um moribundo, em meio às ruínas do paganismo, nos escritos dos últimos clássicos gregos e latinos, de Luciano e de Apuleio. Ela estava, então, em esquecimento desde Homero; e o próprio Virgílio, que uma imaginação terna e melancólica transportava facilmente para as regiões do ideal, não ousara tomar das musas primitivas as cores vagas e terríveis do inferno de Ulisses. Pouco tempo depois dele, Sêneca, mais positivo ainda, chegou até a desapossar o futuro de seu mistério impenetrável, nos coros da Tróade; e então expirou, sufocada sob sua mão de filósofo, a derradeira faísca da derradeira chama da poesia. A musa só despertou por um momento, bizarra, confusa, frenética, animada de uma vida fictícia, divertindo-se com amuletos encantados, tufos de ervas venenosas e ossos de cadáveres, aos clarões do archote das feiticeiras da Tessália, em $O$ asno de Luciano. Tudo o que dela restou desde então até à renascença das letras é este murmúrio confuso de uma vibração que se extingue cada vez mais no vazio e que espera um novo impulso para recomeçar. O que chegou dos gregos e latinos devia chegar para nós.

O fantástico toma as nações em seus cueiros como o rei dos elfos, tão temido pelas crianças, ou vem assisti-las junto ao seu leito de morte, como o espírito familiar de César; e quando seus cantos cessam, tudo finda.

Nossa literatura moderna não foi menos submissa ao espírito da imitação do que a literatura latina. Mas a invasão dos mouros, tão favorável, nesse ponto, ao desenvolvimento moral da Idade Média, já havia transportado para nosso solo o gênio vivaz e produtor das novas poesias. Sem este fato, a literatura clássica, cuidadosamente perpetuada até nós pelo zelo admirável dos monges, erguia-se absoluta e sem intermediário do meio da barbárie, ao primeiro apelo de uma sociedade ávida das luzes do espírito, e foi isto que aconteceu mais tarde, quando a imprensa lançou em circulação, em grande quantidade, as obras da Antigüidade, isto é, uma criação literária pronta. Época singular, em que uma geração de sábios e de poetas reproduziu, repentinamente, os sofistas de Alexandria, os gramáticos do Baixo-império e os versificadores da decadência romana, como um povo 
do Epimênides, inspirados em uma religião, em uma civilização e em uma língua mortas e que diferiam de certo modo de si mesmos somente por esta languidez de órgãos e de imaginação, que trai a tristeza de um longo sonho. Nesse aspecto o fantástico desaparece; mas ele sozinho iluminava a Europa há alguns séculos. Fora ele que havia inventado, ou embelezado, a história das idades equívocas de nossas jovens nações, povoado de visões misteriosas nossos castelos em ruínas, evocado nos torreões a figura das fadas protetoras, aberto um refúgio impenetrável na cavidade dos rochedos ou sob as ameias das muralhas, abandonados à terrível família das guivras e dos dragões. Fora ele que iluminara em sua fronte os fogos do carbúnculo, quando eles atravessam rapidamente o céu como uma estrela cadente, ele que desnorteara os viajantes à margem das águas estagnadas, no traço caprichoso do duende que consolava sua vigília na cabana do lenhador, no canto de uma lareira hospitaleira com jogos inofensivos dos gnomos; que entretinha com doces promessas as esperanças crédulas das jovens, e com doces lazeres o devaneio sedentário dos velhos, que pena! Logo decepcionado pela morte. $\mathrm{O}$ fantástico estava por toda parte então, nas crenças mais severas da vida, como em seus erros mais graciosos, em suas solenidades, como em suas festas. Ocupava a barrinha, a cátedra e o teatro, sentava-se com Alberto, o Grande, nos cadeirados do santuário; com Agripa, no gabinete do filósofo; com Roger Bacon e Paracelso, no laboratório do químico e introduzia a necromancia e a astrologia judiciária até no conselho dos reis. Sua influência nunca será esquecida na literatura em que ela produzia os relatos simplórios das lendas, em que animou com uma pompa tão imponente a crônica dos torneios, das batalhas e das cruzadas, em que se espalhou, até a borda, nas parolas dos velhos contistas e nas trovas dos trovadores. É a ela que devemos os romances de cavalaria, tipo de epopéia inominada, na qual se confundem, com uma harmonia inexprimível, todas as cenas de amor e de heroísmo da Idade Média; amor sem exemplo, no qual não se sabe o que admirar mais, se a pudica ternura da amada, ou o entusiasmo apaixonado do amante; heroísmo ideal, que devia a tudo combater, a bravura dos homens de guerra, a cólera dos reis paladinos, as armadilhas da traição, as desordens da natureza domada pela magia; a intervenção de mil potências inesperadas, modificadas sob aspectos sempre novos, ao sabor da imaginação inventiva do romancista, por todos os possíveis acidentes da fatalidade e que triunfava sobre tudo. Não era mais Juno, Netuno ou Vênus excitados, como na teogonia pagã, pela perda de um homem: era o universo inteiro personificado sob uma grande quantidade de diferentes individualidades e lutando contra um guerreiro coberto, para sua defesa, de sua coragem, de seu amor e de seu justo direito. Não era mais a querela vergonhosa e sangrenta de dois povos obstinados a 
se destruir pela causa, ou pela reparação, do rapto e do adultério: era o processo moral do justo e do injusto, discutido no interesse geral dos homens, entre o céu e o inferno, sob os olhos de uma Helena que era o prêmio e não o objeto, e que mais feliz que o outro, podia desvelar-se sem corar, diante dos dois campos.

Era, deve-se convir, uma poesia maravilhosa, uma ordem de invenções tal que se os antigos tivessem tido os Amadis, talvez não falássemos de Aquiles; uma imaginação ao mesmo tempo grandiosa e fascinante, que não se renovará mais e que se lamentará sempre, como aquela égua de Roland, que era tão bela, tão forte, tão ágil, que imprimiu tão poderosamente sua pata sobre a areia da arena e do campo de batalha, para a qual a mão das princesas bordara a capa e os arreios, e que está morta.

Se eu fosse capaz de nutrir um sentimento de aversão por Cervantes, talvez eu lhe reprovasse por haver contribuído, mais do que todas as pessoas, a nos arrebatar dessas fantasias deliciosas do gênio dos séculos intermediários, que ele destruiu tão facilmente, como Dom Quixote fez com as marionetes de Ginesilho; mas sou obrigado a convir que essa obra de destruição, que nos valeu, aliás, um dos mais belos livros que a imaginação dos modernos produziu, provavelmente foi a condição indispensável de seu destino literário. Quando as fábulas de um povo envelhecem, o instinto impiedoso de mudança que nele reside manifesta-se em seu dia e em sua hora e vem revelar aos homens, por determinados sinais, que é preciso recomeçar a vida social sob novas bases, sem levar em conta as tradições e as simpatias do passado. Ele desencadeia, então, espíritos de desdém, incitados por um rancor irrefletido que transformam em brinquedos o que todos os séculos anteriores veneraram e que brincam com os restos de uma civilização expirante, proferindo palavras de ironia e de desdém, como Hamlet avaliando a cinza dos mortos no túmulo de Iorick e analisando, no crânio de um louco, as forças da inteligência. É dessa forma que Luciano foi remetido ao final do paganismo; Cervantes, depois da cavalaria; Erasmo e Rabelai, com a Reforma; e Voltaire, ao encontro das revoluções políticas que acompanhariam a grande conflagração do cristianismo. Quando uma ordem de coisas morre, há sempre algum demônio engenhoso que assiste rindo à sua agonia e que lhe dá o golpe de misericórdia com um bastão.

O primeiro gênio fantástico da Renascença, por ordem de data e também por ordem de superioridade, é Dante, pois nas obras-primas que o revelam a genialidade não é progressiva. Ele chegou por si próprio e completamente só, no último crepúsculo de uma sociedade acabada, na primeira aurora de uma sociedade nascente; e ainda que ele tenha aberto a carreira, ele a completou totalmente.

É verdade que ele pôs o teatro de sua terrível fantasmagoria sob a 
proteção das crenças de seu tempo, mas o fez seu pelas paixões, pelos atores, e mesmo pelos detalhes da cena, que não são nem homéricos nem virgilianos, mas dantescos. Hoje, freqüentemente encontramos críticos cheios de gosto que deploram o erro dessa magnífica imaginação e a confusão aparente dessa fábula poética, em que o Virgílio da Idade Média toma como introdutor no inferno cristão o Virgílio do paganismo. Essa idéia é, entretanto, o pivô de sua composição e é ela que o torna sublime. O inferno de uma teogonia particular teria sido limitado demais para uma tão ampla criação. Foi preciso que Dante aí se precipitasse na torrente dos séculos, sem respeito pelas formas circunscritas de uma tímida epopéia, e o que conservou das idéias universalmente aceitas, é, ao contrário, uma concessão muito - engenhosa e muito - legítima ao mitismo de sua época, que era, por sua própria natureza, uma das peças essenciais da Divina Comédia, mas que dela não podia formar a alma exclusiva nessa concepção de gigante. Assim, o inferno de Dante não se assemelha a nenhum dos inumeráveis infernos que a sombria melancolia dos poetas inventou e que lembram mais ou menos entre eles o vade in pace do monaquismo e a câmara das torturas da Inquisição. Ele contém em sua arquitetura colossal todos os infernos aptos a receber durante os séculos eternos todas as gerações dos maus. Essa criação atrabiliária não deve ser medida pelo compasso do artista e pelas unidades do retórico. Sua grandeza está na sua liberdade sem freio, no direito conquistado de representar incessantemente no espelho de mil facetas da imaginação todos os aspectos da vida, todos os reflexos do pensamento, todos os raios da alma. Não se deve procurar para ele, não falo um modelo, mas um objeto de comparação, senão no Apocalipse de São João; tampouco é preciso procurar imitadores felizes nos séculos que lhe seguiram, porque esta é uma obra especial de uma época, e o gênio que a concebeu era, sozinho, a expressão de um século cuja individualidade não se pode separar sem a mutilar. $\mathrm{O}$ que dele ficou nos escritos modernos, como o sonho do parricida, em Os Ladrões, como a prosopopéia desesperadora de Jean-Paul, na qual Jesus Cristo vem revelar o vazio eterno às almas inocentes dos limbos, como a visão incomparável do condenado, no romance psicológico de Victor Hugo, é uma emanação local, parcial, inextensível, hoje incomunicável, que trata com toda a autoridade do princípio da qual ela saiu, mas sobre um ponto demarcado, em uma circunstância rara, e através de um meio insensível, como o fogo de um sol que se eclipsa e que ainda inflama a poeira através de uma lente de vidro. $\mathrm{O}$ mundo que a civilização criou para nós não permite mais do que isso.

Assim, a tradição reverenciada da Divina Comédia não produziu uma obra notável do mesmo gênero para o povo da terra que sabe apreciá-la 
melhor. Ela ficou como um monumento inviolável e inacessível dos tempos longínquos, na fronteira extrema da literatura italiana, e o respeito que se aplica às coisas sagradas parece defendê-la para sempre da impotente ousadia dos copistas. A nova mina de invenção que alternadamente, no mesmo país, o espírito, a imaginação, o gênio exploram e, além disso, essa indústria infalível de imitação que se dedica, em toda parte, às musas criadoras, e que termina, nos tempos que chamamos clássicos, para se adornar com suas coroas, era comum à Europa inteira; mas a Itália ainda tinha, sozinha, o privilégio de imprimir às suas descobertas uma marca imortal, porque sua língua estava formada. Coube-lhe enriquecer nossas crônicas e nossos romances com as belezas simples de uma versificação livre e graciosa e, submetendo-as ao metro harmonioso de suas oitavas, ela os libertou, de resto, da censura mais grave de uma crítica desagradável, que tolerou até nova ordem, por condescendência, por Antigüidade, as mentiras rítmicas. Para servir-se da linguagem familiar dessa poesia, seria tão fácil contar as estrelas do céu e as areias do mar quanto as epopéias cavalheirescas da mais engenhosa de todas as idades literárias. Os curiosos conservam disso mais de cem, que são anteriores a Ariosto e que Ariosto fez esquecer, como Homero fizera esquecer as rapsódias de seus antecessores desconhecidos. Que imaginação, de fato, não teria empalidecido ante essa imaginação prodigiosa que subjugou brincando, a suas combinações cheias de graça, de frescor e de originalidade, a tradição de uma história obscura e os devaneios deliciosos de uma mitologia nova, injustamente negligenciada? Diz-se que Hesíodo fora nutrido de mel pelas mãos das filhas do Pindo. Oh! foram as fadas que nutriram Ariosto com alguma ambrosia mais inebriante, e que comunicaram a seus escritos divinos a invencível sedução de seus encantos! Como duvidar da magia quando o poeta, ele próprio mágico, nos conduz, conforme sua vontade, a espaços menos familiares à inteligência do homem que aqueles em que ele extraviou o hipógrifo, quando seus cantos ressentem-se de uma inspiração sobrenatural, e parecem proceder de um outro mundo? Impregnado do estudo dos antigos, ele não recusa desfazer-se de alguns farrapos de seus despojos, mas nunca sem uni-los à aparência, à fisionomia de seus personagens e à livre elegância de suas composições. É ainda independente quando obedece, ainda novo quando imita, e somente se submete à invenção dos outros para a saciedade de suas próprias invenções, cuja profusão o aborrece e o desgosta. Foi que ele furtou o estojo de Alcine ou os tesouros secretos das minas do Catai, e que o pudor da opulência ensina-lhe a misturar, de tempos em tempos, as riquezas mais vulgares àquelas das quais dispõe com facilidade demais. Após Ariosto e seus refutáveis copistas, o fantástico quase não se mostrou mais na literatura 
italiana, o que se compreende muito bem. É que ele se esgotou. Quem acreditaria que essa musa do ideal, filha elegante e luxuosa da Ásia, refugiou-se por muito tempo sob as brumas da Grã-Bretanha? Talvez aterrorizada com as pompas melancólicas do Norte, cujo teísmo lúgubre o levara até ao trono de Odin, e com as vaporosas ficções da Escócia, onde a harpa do bardo somente se casa com o retinir dos espadões e com os rugidos das tempestades, ela procurou, bem depressa, repousar em uma dessas imaginações vivas e joviais que alegraram, com seus cantos voluptuosos, as primeiras festas de seu berço. Veio Shakespeare, que conheceu apenas na muralha de sua ilha, orbe toto divisa, segundo a expressão de Virgílio, as maravilhas do mundo físico, mas que as percebeu em alguma visão sublime e compreendeu os prodígios do reino do sol, como se ele aí estivesse passeando em sonhos nos braços de uma fada; porque Shakespeare e a poesia são a mesma coisa. Spencer não fizera senão lhe traçar o caminho; ele ampliou-o, prolongou-o, embelezou-o com espetáculos novos, encheu-o, inundou-o com novas figuras, mais frescas, mais vaporosas, mais transparentes do que as aparições fugidias dos sonhos da manhã; ele conduzira aí as danças românticas de Oberon, de Titânia, e dos gênios que, com um pé mais leve do que o de Camile tocam também a relva sem a dobrar; semeou aí as flores aromatizadas de perfumes celestes, que se abrem, nos tépidos calores da aurora, para receber o povo noturno dos espíritos, e voltam a fechar-se sobre ele até o anoitecer, como quiosques encantados; ele difundiu no ar luzes desconhecidas, afinou liras celestes que nunca tinham vibrado aos ouvidos dos homens, suspendeu a orquestra melodiosa de Ariel nos ramos vibrantes do espinheiro, escondeu o ninho invisível de Puck em um botão de rosa, e fez brotar de todos os poros da terra, de todos os átomos do ar, de todas as profundezas do céu, um concerto de vozes mágicas. Nas inumeráveis cores da paleta, e nessa grande quantidade de buliçosas simpatias que a palavra toca até o fundo da alma, tudo pertence a Shakespeare. Quando seu pincel terminou de acariciar as formas sedutoras de um silfo, é a ele somente que é reservado esboçar as proporções gigantescas e grosseiras do gnomo sob os traços de Calibã, disfarçar a sátira antiga sob o aparato burlesco de Falstafe, e suspender o esboço de Miguel Ângelo no quadro delicioso do Corrège. Se Dante e Ariosto ainda não lhes ofereceram todas as condições essenciais de individualidade de um semideus, detenha-se neste: incessu patuit.

O que todo mundo sabe muito de nossa literatura nacional responde, por antecipação, às perguntas que poderão me fazer sobre os progressos que nela estavam prometidos ao poema fantástico. Não era no o solo aca- 
dêmico e clássico da França de Luis XIII e de Richelieu que essa literatura, que não viveu senão de imaginação e de liberdade, podia aclimatar-se com sucesso. As mentiras brilhantes do gênio teriam sido tão mal recebidas aqui quanto a verdade. O império do pensamento pertencia, por ordem da Sorbonne e de Aristóteles, aos servidores de uma musa afetada, que arrastava, com privilégio do rei, no teatro da corte e nos salões do Hotel de Rambouillet, os farrapos da Antigüidade travestida. Racine, inspirado em seus velhos dias do gênio dos livros sagrados, ousou muito, por exceção, lançar em uma narrativa temerária a grande figura do espectro de Jezebel, e Voltaire acreditou ter levado mais além a audácia do chefe de uma oposição social que procurou a novidade em tudo, quando ele fizera gritar alguns alexandrinos por meio de um porta-voz pela sombra trágica de Nino. Tivéramos nossas crônicas e nossos romances de cavalaria; porém os respeitáveis intérpretes da Idade Média falavam uma língua ultrapassada que ninguém mais era capaz de entender, e os cavaleiros da Távola Redonda esperaram, por muito tempo, para obter do Olho-de-boi alguma coisa da acolhida a qual estavam acostumados por Carlos Magno, que um introdutor provocante tivesse substituído sua pesada armadura de ferro pelo fraque francês, suas ruidosas esporas pelo tacão vermelho. Os personagens assim vestidos ridiculamente por $\mathrm{M}$. de Tressan, parecem pouco com seu tipo heróico e ingênuo, assim como a lanterna do palhaço no Sonho de uma noite de verão assemelha-se ao luar.

Seria injusto, entretanto, recusar ao grande século a única palma que teria faltado a seus triunfos tão exaltados, e ainda que ele a tenha excessivamente adiado, talvez o futuro mais justo a conceda em compensação à glória abortada de Chapelain, e às admirações um pouco diminuídas que coroaram outrora o soneto de Voiture, o triolé de Ranchin e o madrigal de Sainte-Aulaire. Essa produção digna de fazer época nas mais belas idades literárias, obra prima ingênua, de caráter e imaginação que fará, por muito tempo o encanto de nossos descendentes, e que sobreviverá, sem nenhuma dúvida, com Molière, La Fontaine, e algumas belas cenas de Corneille, em todos os monumentos do reino de Luis XIV, este livro sem modelo que as imitações mais bem-sucedidas deixaram inimitável para sempre, são os Contos de Fadas de Perrault. A composição não está exatamente conforme as regras de Aristóteles, e o estilo pouco figurado, que eu saiba, não ofereceu aos compiladores de nossas retóricas muitos exemplos ricos de descrições, amplificações, metáforas e prosopopéias; teríamos mesmo alguma dificuldade, e digo isso para vergonha de nossos dicionários, de encontrar nesses arquivos amplos de nossa língua esclarecimentos positivos sobre certas locuções desusadas que, pelo menos para os estrangeiros, ainda aguar- 
dam as atenções do etimólogo e do comentarista; eu não nego que há entre todas como: Tirez la cordelette et la bobinette cherra ${ }^{4}$, que poderiam causar sérias preocupações aos Saumaises ${ }^{5}$ futuros; mas o que há de certo nisso é que seus inumeráveis leitores os compreendem às mil maravilhas, e é visível que o autor teve a modesta simplicidade de não trabalhar para a posteridade. Que intenso atrativo, aliás, nos menores detalhes dessas bagatelas encantadoras, que verdade nos caracteres, que originalidade engenhosa e inesperada nas peripécias! Que verve franca e surpreendente nos diálogos! Assim, eu não temo afirmar que, enquanto restar em nosso hemisfério um povo, uma tribo, uma povoação, uma tenda onde a civilização encontra para se refugiar contra as invasões progressivas da barbárie, ele será falado nos clarões da lareira solitária da odisséia aventurosa do Pequeno Polegar, das vinganças conjugais do Barba Azul, das engenhosas manobras do Gato de Botas; e o Ulisses, o Otelo, o Fígaro das crianças viverão tanto tempo quanto os outros. Se há alguma coisa para ser comparada à perfeição sem mácula dessas epopéias em miniatura, se podemos opor algumas idealidades mais frescas ainda aos inocentes encantos do Chapeuzinho Vermelho, aos encantos vivazes de Finette e à tocante resignação de Grisélidis, é no próprio povo que se deve procurar esses poemas despercebidos, delícias tradicionais dos serões do povoado e dos quais Perrault tirou, acertadamente, suas narrativas. Eu não nego que, em nossos dias, se dissertou sabiamente sobre os Contos de Fadas, que se quis encontrar sua origem longínqua, e que a nós cabe somente acreditar na fé dos eruditos de que Pele de Asno é uma importação da Arábia, de que Ricardo, o topetudo não exerceu o direito de feudo, em seus antigos domínios, sem nenhum título de posse selado invocando o Oriente, e que o bolo e o pote de manteiga, apesar de sua falsa aparência de localidade, nos foram trazidos, em uma bela manhã, por algum outro Simbá nas costas de um afrite, do país das Mil e Uma Noites. Acostumaram-nos a tal ponto à imitação, desde o estabelecimento dessa dinastia aristotélica pela qual somos ainda governados do alto do Instituto, que está quase instituído como dogma literário que não se inventa nada na França, e é provável que não faltem boas razões ao Instituto para nos engajar a acreditar nisso. Minha submissão a suas ordens não poderia ir até aí. Nossas fadas benfazejas com a varinha de ferro ou de aveleira, nossas fadas

\footnotetext{
4Tradução literal: "Puxe o cordão e a tramela cairá". São palavras que não têm sentido atual, em nossa língua, porém compõem uma expressão que tem a fórmula mágica, inventada por Perrault que, com esse vocabulário fantasioso, dá à sua narrativa, um caráter antigo e infantil. Trata-se da fórmula que prepara para o mistério e para o perigo que virá diante da porta que se abre. (N. de T.)

${ }^{5}$ Claude Saumaise era um humanista e filólogo. Nasceu em Bourgogne em 1588. (N. de T.)
} 
desagradáveis e rabugentas, com parelhas de morcegos, nossas princesas tão amáveis e tão graciosas, nossos príncipes afáveis e buliçosos, nossos ogros estúpidos e ferozes, nossos matadores de gigantes, as encantadoras metamorfoses do Pássaro Azul, os milagres das Minas de Ouro, pertencem à nossa velha Gália, como seu céu, seus costumes e seus monumentos muito tempo ignorados. É ir longe demais tratar com indiferença uma nação espiritual, que se lançou tão à frente de seu próprio movimento, em todos os caminhos da civilização, contestar-lhe o mérito de invenção necessária para colocar em cena os heróis da coleção Bibliothèque bleue.

Se o fantástico jamais tivesse existido em nossa cultura, com sua natureza especial e inventiva, abstração feita de qualquer outra literatura antiga ou exótica, não teríamos tido sociedade, pois jamais existiu uma sociedade que não tivesse tido o seu fantástico. As excursões dos viajantes não lhes mostraram uma família selvagem que não contasse algumas histórias estranhas e que não localizasse, nas nuvens de sua atmosfera ou na fumaça de sua choupana, não sei que mistérios, surpreendidos no mundo intermediário pela inteligência dos anciãos, pela sensibilidade das mulheres e pela credulidade das crianças. Que os orientalistas apaixonados, que nos furtam as fábulas de nossas nutrizes para com elas homenagear os corifeus das alméias e devadássis, não estivessem sentados, às vezes, sob a palha que cobre a choupana do camponês, ou perto da tenda nômade do lenhador, ou na vigília das parlas dos tasquinhadores, ou na alegre choupana dos vindimadores! Longe de acusar Perrault de plágio, eles se queixariam talvez da parcimônia avara com a qual ele distribuiu aos nossos antepassados essas narrativas surpreendentes das épocas que não existiram e que não existirão jamais, tão presentes e tão vivas ainda na memória de nossos trovadores de aldeias! Quantas belas narrativas eles teriam ouvido, marcadas, com tanta vivacidade, pelos hábitos, costumes e nomes do país, que o etimologista mais intrépido é obrigado, ao escutá-las, a deter-se pela primeira vez na fonte incontestável das invenções e das coisas, e jamais lhe sucedeu de pedir contas disso em seu pensamento a uma outra natureza e a uma outra sociedade! Desde a velha mulher sentimental sonhadora e talvez um pouco feiticeira, que foi a primeira a ter a audácia de improvisar essas trovas poéticas, nas claridades flamantes de um feixe de lenha miúda de zimbro seco, para acalmar a impaciência e as dores de uma pobre criança doente, elas se repetiram fielmente, de geração a geração, nas longas noites das fiandeiras, ao som monótono das rocas, quando muito variado pelo badalar do ferro curvo que revolve as brasas, e se repetirão para sempre, sem que um novo povo se lembre de nos disputá-las; pois cada povo tem as suas histórias e a capacidade criadora do contador de histórias é bastante fecunda em qualquer região para que não seja necessário ir pro- 
curar ao longe o que possui em si próprio, assim como os griôs e os calândares. A propensão para o maravilhoso e a aptidão para modificá-lo segundo certas circunstâncias, naturais ou fortuitas, é inata no homem. É o instrumento essencial de sua vida imaginativa, e talvez seja, mesmo, a única compensação verdadeiramente providencial das misérias inseparáveis de sua vida social.

A Alemanha foi rica nesse gênero de criações, mais rica do que nenhum outro país do mundo, sem disso excetuar esses felizes levantinos, os suseranos eternos de nossos tesouros, na opinião dos antiquários. É que a Alemanha, favorecida por um sistema particular de organização moral, carrega em suas crenças um fervor imaginativo, uma vivacidade de sentimentos, uma misticidade de doutrina, uma tendência universal ao idealismo, que são essencialmente próprios da poesia fantástica; é também porque, mais independente das convenções rotineiras e do despotismo pretensioso de uma oligarquia de supostos sábios, ela tem a felicidade de se entregar aos seus sentimentos naturais sem temer que sejam controlados por essa duana imperiosa do pensamento humano que só recebe as idéias ao peso e ao selo dos pedantes. Essa individualidade meditativa, impressionável e original que caracteriza seus habitantes revela-se de tempo imemorial, em seus inumeráveis monumentos de sua biblioteca fantástica, e lá, ao contrário dos nossos hábitos literários, em que tudo está subordinado à aristocracia do espírito, é a popularidade que consagra o sucesso. A Alemanha desfruta ainda, a esse respeito, dos mesmos privilégios do século de Goëtz de Berlichingen. Ela é devedora disso a essa grande quantidade de circunscrições locais e de usos particulares que nela mantiveram a ingenuidade preciosa dos povos primitivos, que a salvaram da avidez devoradora desta Medusa monstruosa da centralização, cujos braços, inertes para qualquer outro uso exceto para apoderar-se, só se ocupam em saciar a fome insaciável da Górgona, e que a manterão até o fim da nossa civilização presente, não importa o que disso digam nossos teóricos de clubes e de cafés, na primeira fila das nações livres. Desde a bela história de Fausto, poetizada admiravelmente por Goethe, que nada acrescentou, por outro lado, à idealidade filosófica da invenção, desde a profunda alegoria do aventureiro que vendeu sua sombra ao diabo, e que o último rapsodo que a compilou só a reduziu às formas acanhadas do romance, a Alemanha foi, até os nossos dias, o domínio favorito do fantástico. Ela completou a história psíquica do homem, tão magnificamente aberta no Gênesis pelo emblema verdadeiramente divino da árvore da ciência e das seduções da serpente. Fausto é o Adão do Paraíso terrestre, elevado a crer-se igual a Deus. O Sonho de Jean-Paul é o desfecho solene desse triste drama, e esse outro Apocalipse, a terrível palavra do enigma de nossa vida material. Salvo essas 
três fábulas, não existe verdade absoluta sobre a Terra.

Os infortúnios cada vez maiores da nova sociedade pressagiavam tão visivelmente sua ruína imediata que a trombeta do anjo dos últimos dias não a anunciará mais distintamente à geração condenada. Desde esse instante, o fantástico irrompeu em todas as vias que conduzem a sensação à inteligência: eis como ele ingressou, apesar de Aristóteles, Quintiliano, Boileau, La Harpe e outros, no drama, na elegia, no romance, na pintura, em todos os jogos do espírito, como em todas as paixões da alma. E então esse foi um grito de cólera amarga e ignorante contra a invasão inopinada que ameaçava as belas formas do clássico; e não se compreendeu que existisse ainda uma forma mais ampla, mais universal, mais irreparável, que fosse terminar; que essa forma era aquela de uma civilização desgastada, cujo clássico fosse apenas a expressão parcial, momentânea, indiferente, e que não era surpreendente que os laços pueris das unidades ridículas da retórica se afrouxassem, quando a imensa unidade do mundo social se rompesse por toda parte. Entre os homens eleitos que um instinto profundo do espírito lançou, nesses últimos tempos, à frente das literaturas, não existe quem não tenha sentido a advertência dessa musa de uma sociedade que tomba e quem não tenha obedecido às suas inspirações, como à voz imponente de um moribundo cuja cova já está aberta. A escola romanesca de Lewis, a escola romântica dos lackistas e, acima de tudo, os grandes mestres da palavra, Byron e Walter Scott, e Lamartine e Hugo, aí se precipitaram em busca da vida ideal, como se um órgão particular de adivinhação, que a natureza ofereceu ao poeta, lhes tivesse feito pressentir que o sopro da vida positiva estava prestes a se extinguir na organização caduca dos povos. Não nomeei, entre eles, Chateaubriand, que permaneceu, por consciência e por escolha, ao término do mundo antigo, como a pirâmide nas areias do Egito, como a arca do dilúvio no alto do Ararat, como as colunas de Hércules nas praias de mares desconhecidos. Walter Scott, acorrentado também por lembranças, estudos e afecções, colocou um pouco mais longe, mas não com mais solidez e potência, as bases de seu renome vindouro entre as duas sociedades. É um farol que lança indistintamente algumas luzes sobre o porto, algumas luzes sobre o abismo. $\mathrm{O}$ abismo! Byron aí se perdeu com todas as velas, e olhar humano algum pôde aí segui-lo.

O fantástico da Alemanha é mais popular, e isso se explica, eu o repito, por uma prolongada fidelidade aos costumes da tradição, às instituições expulsas do país e freqüentemente defendidas e salvas ao preço do sangue dos cidadãos; a um sistema de estudos mais geral, mais bem entendido, mais apropriado às necessidades do tempo. Isso se explica, principalmente, por uma repugnância pronunciada pelas inovações puramente materiais, nas quais o princípio inteligente e moral das nações nada tem a ganhar. 
Esse povo, que tocou os limites de todas as ciências, que produziu quase todas as invenções essenciais cujo impulso completou a civilização da Europa, e que se ocupa deliciosamente, na doce posse de uma liberdade sem pompa, com as contemplações sedentárias da astronomia e com o enriquecimento das nomenclaturas naturais, merecia conservar por muito tempo o gosto inocente e sensato pelos contos infantis. Graças sejam prestadas a Musoeus, a Tieck, a Hoffmann, cujos felizes caprichos, alternadamente místicos ou familiares, patéticos ou bufões, simples até à trivialidade, exaltados até à extravagância, mas plenos de originalidade, de sensibilidade e de graça, renovam para os velhos dias de nossa decrepitude as frescas e brilhantes ilusões do nosso berço. Sua leitura produz, em uma alma fatigada das convulsões da agonia desses povos inquietos que se debatem contra uma crise inevitável, o efeito de um sono sereno, povoado de sonhos sedutores que a embalam e a repousam. Essa é a fonte da Juventude da imaginação. Na França, onde o fantástico é hoje tão depreciado pelos árbitros supremos do gosto literário, talvez não fosse inútil procurar sua origem, marcar acidentalmente suas principais épocas e atribuir a nomes muito gloriosamente consagrados os títulos culminantes de sua genealogia; mas só esbocei os traços tênues de sua história e me absterei de fazer sua apologia contra os espíritos sabiamente prevenidos que abdicaram das primeiras impressões de sua infância para se entrincheirar em uma ordem de idéias exclusiva. As questões sobre o fantástico são propriamente do domínio da fantasia. Deus me guarde de despertar, com relação a esse assunto, as miseráveis disputas dos escolásticos dos últimos séculos, e de transportar uma querela teológica para o terreno da literatura, no interesse da graça das feerias e do livre arbítrio do espírito! O que ouso crer é que se a liberdade da qual nos falam não é, como às vezes temi, uma decepção de trovadores, seus dois principais santuários estão na crença do homem religioso e na imaginação do poeta. Que outra compensação vocês prometem a uma alma profundamente dilacerada pela experiência da vida, que outro futuro poderá ela preparar para si, de ora em diante, na angústia de tantas esperanças desgraçadas, que as revoluções levam com elas, pergunto-lhes, homens livres que vendem aos maçons o claustro do cenobita, e que sustentam a mina sob o retiro do solitário, onde ele estava refugiado ao lado do ninho da águia? Vocês têm alegrias para devolver aos irmãos que repeliram, que possam indenizá-los da perda de um único erro consolador, e se crêem bastante seguros das verdades que às nações fazem pagar tão caro, para estimar sua árida amargura ao preço do doce e inofensivo devaneio do infeliz que volta a adormecer com um sonho feliz? Entretanto, tudo goza em vocês, é preciso dizê-lo, de uma liberdade sem limites, a não ser a consciência e o espírito. E não sabem que sua marcha triunfal através das idéias 
de uma geração vencida, todavia não envolveu de tal forma o gênero humano, que não permaneçam ao seu redor alguns homens que têm necessidade de se ocupar de outra coisa, além de suas teorias, de exercer seu pensamento em uma progressão imaginária, provavelmente, mas que não é talvez mais do que sua progressão material, e cuja previsão não é menos adequada que a das tentativas de seu aperfeiçoamento social sob a proteção das liberdades que invocam! Vocês esquecem que todo o mundo recebeu, como vocês, na Europa viva, a educação de Aquiles, e que não são os únicos que romperam o osso e as veias do leão para sorver seu tutano e beber o seu sangue! Que o mundo positivo lhes pertence irrevogavelmente é um fato e provavelmente um bem; mas quebrem, quebrem essa cadeia vergonhosa do mundo intelectual, com a qual se obstinam a constranger o pensamento do poeta. Há muito tempo tivemos, cada um à sua vez, nossa batalha de Philippes; e muitos não a esperaram, juro-lhes, para convencer-se de que a verdade era apenas um sofisma e que a virtude era somente um nome. Para esses, é necessária uma região inacessível aos movimentos tumultuados da multidão para aí colocar o seu futuro. Essa região é a fé para os que crêem, o ideal para os que sonham e que preferem, para tudo compensar, a ilusão à dúvida. De resto, seria necessário, depois de tudo, que o fantástico retornasse para nós, não importa os esforços que se fizessem para proscrevêlo. $\mathrm{O}$ que se desarraiga mais facilmente em um povo não são as ficções que o preservam: são as mentiras que o iludem. 